\title{
The Tempest: A Negotiable Meta-Panopticon
}

\author{
Hanieh Mehr Motlagh \\ English Literature Department, University of Tehran, Alborz Campus Karaj, Alborz, Iran \\ E-mail: mehrmotlagh@ut.ac.ir
}

Doi:10.7575/aiac.alls.v.6n.2p.212

Received: $16 / 12 / 2014$

URL: http://dx.doi.org/10.7575/aiac.alls.v.6n.2p. 212

Accepted: 18/02/2015

\begin{abstract}
In The Tempest, Shakespeare represents a world in which the model of a panopticon within a panopticon reveals how the power relations functions. All the major and minor characters establish panopticons which start from their own bodies and soul and move toward the larger one which belongs to that of Prospero as the higher order who has access to a magical power and a mysterious police force. As a social group is formed in the play, the individuals in that group seek to make use of the process of testing, recording, explaining to provide obeying subjects. There are negotiations between the subversive voices and the rulers which expose the issue of containment as a personal, social, and cultural production rather than a coercive factor.
\end{abstract}

Keywords: panopticon, subversion, containment, discipline, punish, negotiation

\section{Introduction}

Pertaining to Foucault's "Discipline and Punish" and Greenblatt's theory of "Subversion and Containment" the writer of the present article considers Shakespeare's The Tempest (1611) a meta-panopticon play in which almost all the characters are caught up in a sort of panopticon within a panopticon and the individuals gain chances for subversion. The subversive voices are contained, however there are opportunities for the lower orders to negotiate with the higher order. So far the issues of panopticon and the police surveillance have been analyzed with regard to the state as the absolute power. However scrutinizing the language of the characters and the meta-panoptic model of The Tempest in the present article, the writer attempts to expose the panopticism as a structure in which there are other panopticons. In this play the police surveillance functions separately at some points and is as a unified whole at some other.

William Shakespeare (1564-1616) a poet and playwright, is regarded as the English national poet whose sonnets and plays are widely read. He began his profession as a writer of comedies and histories and later he started working on tragedies among which Hamlet (1600-1601), Othello (1604-1605), Macbeth (1605-1606), and King Lear (1605-1606), are regarded as the finest one. The styles of his works are conventional style of the day and his poetic form was blank verse. Almost at the end of his life he got interested in writing Romance and tragicomedy, consequently he wrote Cymbeline (1609-1610), The Winter's Tale (1610-1611), and The Tempest (1611-1612) as the most noteworthy among his works during this period. At the end of his career, Shakespeare was influenced by a sense of redemption, thus he is more symbolic in his later works. There are a lot of probable literal sources for writing The Tempest, however it seems that there is a farewell to art by Shakespeare, or as Marie Merkel believes it is a farewell to Prince Henry because of his death (Shakespeare, p.1).

The Tempest relates the story of Prospero who is deprived of his right of being the Duke of Milan and is banished to an island to live there with his three-year-old daughter called Miranda. During twelve years, Prospero takes the control of the black Caliban and the island and learns how to manipulate everyone through using a magic staff and circle. A royal group (King Alonso, Sebastian, Antonio, and Gonzalo)'s ship is wrecked in the storm and they enter the island. Recognizing the group as those who took his rights, Prospero schemes to take revenge. Meanwhile Ferdinand (the son of the king) who is brought by the sea to another side of the island falls in love with Miranda. During the course of the play, the royal Antonio and Sebastian plot to murder Alonso in order to seize the throne. Prospero observes and controls everything through the magic sphere, necessary punishments, and Ariel's helps, however ultimately he decides to pardon all.

Many critics have analyzed The Tempest from different perspectives, but none has rendered a Foucaudio-New Historicist reading with regard to the meta-panoptic aspect of the play. Although some of them have explored the main concerns of the article such as Foucault's power and power relations, discipline and punish, and Greenblatt's historical aspects of the play considering the issues of subversion-containment in colonialism, none of them has provided an amalgam of the two readings. There are many critics who have surveyed the play from Foucault's outlook regarding power relations, for instance in Shakespeare in French Theory (2014), Wilson investigates the historical changes that happened in the format of power and language during Renaissance and refers to The Tempest as a system of discipline and panopticon from above.

In Moments of Negotiation (2001), Pieters renders how "the reading of early modern period by Torodov, De Certeau, and Foucault" can be associated with Greenblatt's ideas (p.67) and how disciplinary power is sustained although 
Shakespeare's plays reveal that power is vulnerable (p.72). Pieters also refers to Foucault's ideas on "power of govermentality" (p.73), however he does not provide an in-depth analysis of The Tempest based on the notions of these two thinkers. Carey-Webb remarks the panoptic structure of the play in Making Subject(s) (2014) and introduces Prospero and Ariel as the agent of Foucaudian gaze.

The ideas of subversion and containment in Shakespeare's dramatic works have been scrutinized by many critics. In Shakespearean Negotiations (1988), Greenblatt discusses these notions in one chapter, yet he only relates the idea of authority and power from above in The Tempest in another chapter. In a comprehensive essay, Dollimore explores the essence of order during the Elizabethan era and describes the process of "Consolidation, subversion, containment" (1994, p.10) from the Cultural Materialist ${ }^{i}$ perspectives he views Shakespeare's plays as the representation of the English culture. Dollomire refers to Shakespeare's plays such as Richard II which was played forty times in England and in this sense, it is the representation of the Elizabethan political containment (1994, p.8). In The Purpose of Playing (1996), Montrose regards the issue of subversion and containment as a strong and "closed conceptual structure" (p.9) and Hawkes believes that Shakespeare's plays represent how the absolute power sustains itself in the society (2005) through the process of containment.

Greenblatt analyzes Shakepeare's Henry plays through the magnifying glass of subversion-containment in an article called "Invisible Bullet" (1988) in which he proposes an anecdote concerning an Indian colony and later he epitomizes the theory on two parts of Henry IV and Henry V. In "Are We Being Historical Yet?" Ben R. Schneider considers The Tempest a colonist play and explores the containment of the marginalized individuals by the colonizer. In The Routledge Guide to William Shakespeare (2013), Shaughnessy refers to the colonial ideology and insubordination in the play. Likewise Lim regards the protagonist of the play as an oppressor who colonizes the alien other and he reveals how the subversive factor is silenced in order to save the power from any threats. He scrutinizes the reflections of colonialism and marginalization of the Other in Europe in The Tempest (1998).

The present article exposes a Foucaudio-New Historicist reading with regard to the selected theories of Foucaudian "Discipline and Punish" and Greeblattian "Subversion and Containment" to provide the answers to the following questions: how does Shakespeare portrays panopticon within panopticon, how does the process of containment works through language, and what are the points of negotiation between the higher and lower orders? The answers to these questions reveal that the model of the power structures in the society of The Tempest is a meta-panopticon that is willfully constructed socially and culturally. The process of containment of the subversive forces is done though negotiations with the higher order in each social group based on the matter of personal privileges.

\section{Foucault's Theory of "Discipline and Punish"}

Michel Foucault (1926-1984) is one of the most prominent European thinker, writer, and critic in the twentieth-century. He has influenced post-structuralism, new historicism and cultural studies. Along with different notions, Foucault has worked on "deconstruction of the self", "subject", "knowledge" and "power". He has a special outlook toward power, thus as Danaher remarks, power for Foucault is not something used by individuals and groups. It is a set of relations between various groups of society which changes in different circumstances and times (2002, p.118). According to Foucault, we should consider power a collection of relations. For Foucault, power is not a material, it is not a position or a criteria. He believes that there is no specific subject for power, yet there is no power without a specific reason and purpose (2004, p.550).

As Dreyfus and Rabinow remark, unlike in the past that power belonged to the king, government or a special group, today power is impersonal, distributed, relative and unnamed (1983, p.21). According to Foucault, power can be a producer and its main product is knowledge. He stops asking where and how power comes from, because in this way we lose a collection of sophisticated truths (2004, p.550). This type of questioning power belongs to the traditional study. He questions how power is put into action, what happens when people show their power. To answer these questions, there should be an accurate description of power and power relations. It should provide enough data on how different means and technologies are used to render power.

Foucault discusses the role of the "body" in "Discipline and Punish" and believes that it is entangled in a political field where power relations make the use of it when they "invest it, mark it, train it, torture it, force it to carry out tasks, to perform ceremonies, to emit signs," consequently the body becomes beneficial through subjection which is gained by physical coercion (2004, p.549). Traditionally it was believed that the one who has power gradually obtains knowledge from outside, however Foucault in the same article mentions that there is a reciprocal relationship between power and knowledge. There are no power relations without the proper knowledge and likewise there is no knowledge without the well structured power relations (2004, p.550). Foucault goes beyond the old view that states knowledge is good and brings power to people. According to Danaher, he believes that knowledge makes people subjects as they make sense of themselves by referring to different bodies of knowledge. In order to be successful and accepted in an institution, one is supposed to follow the rules so that the institution can monitor their progress in various ways. In this way, people are made as certain approved types of individuals by discipline and knowledge (2002, p.50).

As it is mentioned in "Discipline and Punish," due to the widespread epidemics of plague in the seventeenth century in England, the government started to control and monitor everything. Thus individuals were inserted in fixed places and any movements would have been punished either by those in charge or by the disease and death (2004, p.552). As the power was visibly exercised, there was the omnipresent gaze by the guards and the officers and power was exercised without division. That happened while all the individuals, the sick and the dead, were living among the living beings 
without any divisions, yet in the nineteenth century, the "lepers" were recognized as symbolic inhabitants such as beggars, madmen and the disabled population. During those circumstances, they tried to exercise power by separating the individuals; "mad/sane; dangerous/harmless; normal/abnormal" (2004, p.553).

Gradually the rites of confinement were devised through a new disciplinary mechanism in which segmentation and invisibility of power became of the most important issue. Wilson quoting Foucault states that during Renaissance power of the state changed from a "spectacle of the public suffering" to the private punishment in order to "insert the power to punish more deeply into the social body" (qtd. Wilson, 2014, p.82). Borrowing Bentham's panopticon, Foucault believes that this system of exclusion is similar to the architectural figure of "an annular building" with a tower at the center. The guards in this tower can invisibly supervise all the inmates in the cells which have surrounded the tower 2004, p.554).

Foucault asserts that this structure functions the opposite of the "principle of the dungeon," since the tower is highly lighted and illuminates all the cells $(2004$, p.554). Consequently the prisoners feel like being under constant surveillance and they undergo the process of rehabilitation and in this manner according to Foucault power is individualized and anyone can operate the machine (2004, p.555). However Wilson in quoting Marc Shell, states that visibility is a trap since the one in power makes both himself and "visible things invisible to others" (qtd. Wilson, 2014, p.122). Likewise according to Rey Chow, light is not used as a means of purgation, however it makes the inmate to be seen and caught easily (2012, p.157), consequently the ocularcentrism is at the service of the rehabilitative force.

According to Foucault in "Discipline and Punish," during the history the disciplinary power of the state was distributed among the "private religious groups," and "parish guilds or charity associations," whose functions were "to punish by confinement a whole infra-penality, that of disorder, agitation, disobedience, bad conduct" and gradually the modern police power was formed. The sovereignty used the police force to assign his orders. Thus it should be present everywhere to supervise everyone (2004, p.559). It functioned both as the "auxiliary of justice" and a disciplinary power which was a repressive tool for monitoring the "plots, opposition movements, or revolts." Consequently the absolute power was back in the hands of the monarch to fix the subjugation of the subjects $(2004$, p.560).

\section{Greenblatt's Theory of "Subversion and Containment"}

Stephan Greenbalatt (1943) argues his theory of "Subversion and Containment" in an "Invisible Bullets," in which using an anecdote, he analyzes the process of containment in a colonized Indian society. This process is consists of three steps revealing how power of the state is sustained well especially when the mechanism begins among the simple minded lower class people. Later he epitomizes his ideas on Shakespeare's Henry plays and follows the ways through which the prince and the King justify their rightfulness and authority by the same process. What is noteworthy is the fact that the traces of this strategy of sustaining power can be followed in the power structures of the modern and postmodern societies as well.

According to Greenblatt in his article "Invisible Bullets," the first step in the process of containment is "testing upon the bodies and mind" of the individuals. This testing can be done with regard to the religious beliefs to recognize the changes that happen in the ideas of the individuals $(2004$, p.438) and any kinds of disbelief in the religion would be considered a symbol of corruption (2004, p.436). He argues that whenever a crisis happens in the society, the individuals' notions of theological guardians become unstable, thus there is a "crisis of belief" as well. Consequently there would be a suitable time for the authority to coerce its own beliefs (2004, p.439). In this case, the aids coming from the power from above would be a wonderful supplement for the religion, in that, it solves the problems of the inhabitants of the society and provides their basic requirements especially during the critical moments.

The second step in the process of containment is the issue of recording the other's voice. Greenblatt in the same article asserts that for recording "the alien voices," learning the language of the other is of the prime importance (2004, p.448), since they are have the potential for subversion in the social world $(2004, \mathrm{p} .449)$. He believes that exploration of the others thoughts for the purpose of correction, change, and discipline are necessary $(2004, \mathrm{p} .442)$ so that the authority can kill two birds with one stone. On the one hand, as Greenblatt mentions "the possibility of plentitude" are nullified (2004, p.442), and all negative and opposing forces can be recognized and treated by physical and ideological coercions. On the other hand the authority represents itself as positive hearing ears which work for the good of the subjects, consequently at this level, subversions are contained to some extent. Therefore the need for the police state as a controlling force and a medium in the hands of the ideology to create an unrelenting gaze is inevitable.

In the third step which is called explanation, as Greenblatt argues in "Invisible Bullets," in the case of the confrontation with some critical moments, the ideology is regarded as not fully rightful, thus it requires to explain its policies in order to justify itself to its subjects (2004, p.442). According to Greenblatt this explanation is an "impeccable reasoning" on the surface, however there is the matter of "self-interest" behind it. In this step religion glorifies the power through providing "public justification" for the ideology $(2004$, p.453) and there is a promise of support for the religious authorizes on the side of the ideology, thus a reciprocal relationship between the ideology and religion is formed.

Greenblatt in "Invisible Bullets," believes that although such opposing ideas are suppressed by punishment and ultimately they are contained, "subversiveness is the very product of that power and furthers its ends." Therefore in many cases power is built based on the existence of subversion and the attempts to set up order in the society (2004, p.439). Many critics have criticized this theory because of the fact that there would be an entrapment model from which there is no way to escape. Yet Fumerton and Hunt quoting Leinwand state that Greenblatt does not render a totally pessimistic ideas through this process, however he represents a model in which there are chances for negotiations, thus 
there would be some opportunities for resistance and change from the lower orders as well (qtd. Fumerton, P,\& Simon H, 1999, p.313). Grady in "Containment Subversion - and Postmodernism" asserts that the containment theory is a cultural production (1993, p.36) and in the "Invisible Bullets" there are more chances for "negotiation" with the society around it than it is often noticed (1993, p.37).

The next issue, for which Greenblatt is well-known, is the matter of self-fashioning. He introduces self-fashioning as "representation of one's nature or intention in speech or actions" (2012, p.3). He believes that it is a cultural mechanism of meaning that molds a special type of individual during the history. He explores a set of governing features and finally comes to a conclusion that self-fashioning happens when there is a confrontation between the "authority and an alien." By the formation of identity, the signs of subversions are contained within the individual (Greenblatt, 2012, p.9). Literature is influential in the creation of a culture during a specific era, since it provides a perfect ground for exploration of how behavior of the writer is shaped and it reveals the standards by which that behavior is structured in a particular era (Greenblatt, 2012, p.3-4). Likewise he remarks that the internalization of the social accepted standards aids the individuals to obtain a "self-fashioning" state (Greenblatt, 2012, p.3). Greenblatt believes in the importance of language and the fact that social deeds have cultural implications which become meaningful through interpretations. He states that "Language, like other sign systems, is a collective construction; our interpretive task must be to grasp more sensitively the consequences of this fact by investigating both the social presence to the world of the literary text and the social presence of the world in the literary text" (Greenblatt, 2012, p.5).

\section{The Tempest as a Panopticon within a Panopticon}

Analyzing the language of the characters in the play with regard to Foucauldian theory of "Discipline and Punish" and Greenblatt's notion of "Subversion and Containment", the article reveals the labyrinth of panopticons in The Tempest which starts from the major one represented as Queen Elizabeth's state and later it moves toward minor ones as Shakespeare (as the writer), the theatre, the theatre goers, and the major and minor characters. Despite the negative connotations that this structure may have, they are indeed the required factors for the perseveration of disciplined individuals and society. The primary minor panopticons that are biologically, personally, socially, and culturally constructed, initiate from within each individual. In The Tempest the power relations in each group create power structures which are not thoroughly suffocating, however there are occasions when the subjects and the rulers discuss a settlement. The panoptic within the panoptic in this play is the same as Figure 1.

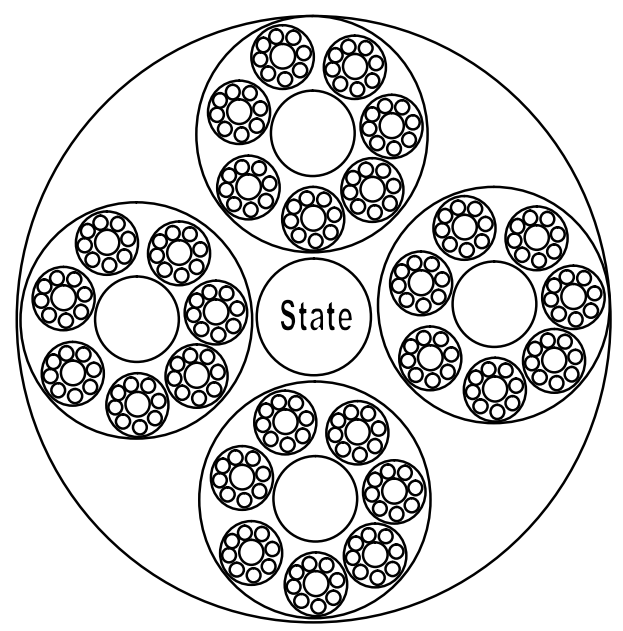

Figure 1. The panoptic within the panoptic

The above picture represents the fractal ${ }^{\mathrm{ii}}$ structure of a society which functions based on the meta-panoptic model from above. In most cases, in each institution such as schools, prisons, hospitals, universities, companies, and so on there is a basic supervising section either visible or invisible based on the purpose of the individual in charge. Actually the panopticon within the panopticon starts from the sun at the center of the Milky Way (if not from God as the head of the universe), then it moves to the head of the state and continues to the minor ones. Ultimately there is an atom as the smallest unit of matter which is composed of a nucleus at the center and some electrons which are incessantly moving around the center.

Considering Queen Elizabeth's Panopticon, she is the center of the state and she assigns Shakespeare as a shaper to mold her subject's minds based on the dominant ideology. Therefore as Foucault in "Discipline and Punish" states, since the disciplinary power of the state is distributed among the institutions and in this sense the police power is emerged (2004, p.559), Shakespeare is a kind of police state who manages people's minds or according to Montrose, he "shapes the fantasies by which it is shaped" (2004, p.504). The next panoptic structure is associated with the theatre in which the audiences stand for the tower at the center and they have the stage and the characters under their unrelenting gaze. The police forces in the theatre panopticon are the usher-who prevents any chaos among the audience- and the director of the play-who tries to control any disruptions during the course of the play on the stage. Likewise Ferdinand, who enters the panoptic island, is similar to a spy for the spectators and provides a pleasing opportunity to have a close 
look on Prospero's private life. This notion is apparent in Propero's speech: "and hast put thyself/Upon this island as a spy, to win it/ From me" (1993, 1.2. 455-457).

In The Tempest God's great panopticism and his gaze upon his subjects are indicated by Prospero when he claims that when they were forced out of Milan, Miranda and him were saved "by Providence divine" (1993, 1.1.159). Also Prospero as the major characters provides a great panoptic surveillance in the island which is alive "with an eye of green in't" (1993, 2.1.56). Based on what Carey-Webb states, Prospero uses magic and Ariel as his all-seeing forces to manipulate the people's actions. He is the invisible power that observes all (2014, p.75). Ariel functions as a secret police force in Prospero's kingdom. He is described as "an airy spirit" in the dramatis personae and at the same time the source of information. Thus in this case he is similar to a highly technological secret computer device which has an artificial intelligence, a virtual data base and is linked to the internet. Ariel epitomizes a listening device, a monitoring device, a torturing machine, an executioner and also a threat and a subversive force to the source of power as well. As Prospero is demanding a report on his mission, Ariel replies:

I boarded the king's ship; now on the beak,

Now in the waist, the deck, in every cabin,

I flamed amazement: sometime I'ld divide,

And burn in many places; on the topmast,

The yards and bowsprit, would I flame distinctly,

Then meet and join. Jove's lightnings, the precursors

O' the dreadful thunder-claps, more momentary

And sight-outrunning were not; the fire and cracks

Of sulphurous roaring the most mighty Neptune

Seem to besiege and make his bold waves tremble,

Yea, his dread trident shake. (1993, 1.2.196-206)

From time to time Ariel delivers all the news of the island to Prospero. Likewise Prospero's circle, from which he monitors the entire island, is similar to Bentham's tower which is an invisible source of power, as Wilson remarks (2014, p.109). When Prospero sends Ariel to supervise the royal group he demands him to function as a Foucauldian unrelenting gaze: "be subject /To no sight but thine and mine, invisible/ To every eyeball else" (1993, 1.2.301-303).

As a subversive force and a threat to Prospero's authority, Ariel dares to questions the higher order: "Is there more toil? Since thou dost give me pains/ Let me remember thee what thou hast promised/ Which is not yet perform'd me" (1993, 1.2.242-244). Based on what Greenblatt states, one of the ways in the process of containment is "testing upon the bodies and mind" of the individuals" (2004, p.438), consequently Prospero comes to a conclusion that testing of Ariel's beliefs repeatedly should be done: "Once in a month recount what thou hast been/ Which thou forget'st" (1993, 1.2.261-262). According to Greenblatt's notion of recording "the alien voices," learning the language of the other is of the prime importance ("Invisible Bullets," 448), therefore using the process of containment, Prospero tries to record Ariel's speech through asking "how now? moody?/ What is't thou canst demand?" (1993, 1.2.244-245) and soon he explains that "before the time be out? no more!"( 1993, 1.2.246) and he continues to ask if he has forgotten how Prospero saved him $(1993,1.2 .251)$. In this sense, Greenblatt asserts that the authority explains its policies in order to justify itself to its subjects (2004, p.442) and during these dialogues a kind of negotiation emerges, therefore as Grady claims, there is chance of bargaining in the process of containment (1993, p.37). Prospero manipulates his servant's mind by reminding him whatever he has done for Ariel's sake and in return Ariel gets sure about gaining his freedom when Prospero promises to set him free after two days on the condition that he is obedient in complying Prospero's instructions (1993, 1.2.298-299).

In "Discipline and Punish" Foucault states that the disciplinary power punishes any kinds of disorder and disobedience (2004, p.559), thus Prospero as a higher order, warns Ariel of any misconduct: "If thou more murmur'st, I will rend an oak/ And peg thee in his knotty entrails till/ Thou hast howl'd away twelve winters" (1993, 1.2.294-296). According to Wilson, Prospero cleanses the wrongdoers by fire and water and removes the dirt from their bodies and souls (2014, p.108): "So safely ordered that there is ... not so much perdition as an hair/ Betid to any creature" (1993, 1.2.30-31) purified, "On their sustaining garments not a blemish" (1993, 1.2.218). Also Prospero threatens Caliban to get punishment: "For this, be sure, to-night thou shalt have cramps/ Side-stitches that shall pen thy breath up" (1993, 1.2.325-326).

As it is mentioned before, there is a spectator panopticon which observes the stage and the characters incessantly. Prospero reveals this awareness after the masque by mentioning that "our revels now are ended. These our actors,/ As I foretold you, were all spirits" (1993, 4.1.148-149). According to Campos in an essay, Prospero does not expose his plans to the audience even when he is all alone on the stage, thus he sustains his public image as a well natured man with benevolent purposes. In this sense he seems to be a genius Machiavellian who does self-fashioning so that he can shape his subjects' minds as well of that of the spectators (2004, pp.209-210). He tries to justify his actions in minds of the audience in order to make them sympathize for him. However looking for his own self-interest, Prospero has the potential for subversions as well. 
Caliban is a subversive force who tends to disobey his master from time to time. He is the "alien voice" that should be well heard and recorded, therefore learning the language of the other is significant, as Greenblatt asserts (2004, p.448). The process of containment is apparent at this part of the play when Caliban claims that Prospero taught him "how/To name the bigger light" (1993, 1.2.335) and he asserts: "You taught me language... The red plague rid you/ For learning me your language!" (1993, 1.2.363-365). Prospero listens to Caliban carefully and finally decides to manipulate his mind and to explain and justify his actions on the island: "I have used thee/Filth as thou art, with human care, and lodged thee/In mine own cell, till thou didst seek to violate/The honour of my child" (1993, 1.2.345-348). Consequently Caliban and Prospero enter a negotiation. On the one hand, Caliban discusses what Prospero has done to him in possessing the island and on the other hand, Prospero justifies himself by mentioning that all he has done have been for Caliban's own goodness and how he toiled so much to teach him language (1993, 1.2.253-255).

Miranda is the next subversive force in the play who disobeys her father's order by telling her name to Ferdinand and by proposing to him: "I am your wife, if you will marry me," (1993, 3.1.83) however she is also at the moment of the process of containment when she begins to test Ferdinand by asking him: "My father/ Is hard at study; pray now, rest yourself" (1993, 3.1.19-20). Prospero invisibly supervises Miranda and state that she is "infected" (3.1.31). Both Ferdinand and Miranda enter a bargain of affection, meanwhile Miranda tries to justify her wish for his love. Ultimately she obtains her aim when Ferdiand offers his heart "as willing/ As bondage e'er of freedom: here's my hand" (1993, 3.1.88-89). According to Prusko, through internalization of his father's codes of behavior, Miranda begins to control his father's discourse, since she tries to obtain power beyond Prospero's devised standards. She tries to establish a historical background by asking about her past and later she gains a sense of self as a teenager (2013, p.7).

Regarding the models of the minor panopticons in The Tempest, the first instance is apparently structured in ACT I. The play begins with a struggling ship in the storm and right from the beginning reveals a power relation in which due to the windowed building at the center of the ship, the superstructure resembles a panopticon. According to what has been mentioned in the website Officer Ranks in the Royal Navy, the crews ranking ranges from Master, Surgeon, Purser, Boatswain, Carpenter, and Gunner accordingly. A master is regarded as a "professional seaman" who supervises the crew and "command[s the] ship" (2000, p.1). Since a ship can stand for a micro-society, based on this website, a master deciding about the ship's position and keeping it in the right track, is considered an authority on a ship. Boatswains are supposed to stand and supervise everything on the deck $(2000$, p.1), thus they are similar to the police force and the Faucouldian gaze.

The next minor panopticon structures are associated with individuals either from the lower order or the higher order in The Tempest. Each individual epitomizes a panoptic model which is like "a temple", as Miranda explains: There's nothing ill can dwell in such a temple/ If the ill spirit have so fair a house/ Good things will strive to dwell with't" (1993, 1.2.458-460). Depending on each individual's "conscience" to which Prospero refers as well (1993, 1.2.471), he/she is made up of combination of the internal power and the police who has self-observation and repentance. Prospero is not a vicious cruel person, since he has a sane conscious and has the power to act like the one who has a compassionate soul. He reveals this quality when he is worried about the safety of the royal group after the storm in ACT I (1993, 1.2. 217).

Considering each individual's panopticon, Prospero releases Ariel, sets aside the magic staff, book, and the all seeing circle, he becomes his own ruler and police state. Likewise Gonzalo is the one in whom the amalgam of power and police force makes him a "noble" man who "Out of his charity, being then appointed Master of this design," (1993, 1.2.161-163) helps Prospero and Miranda to get out of Milan safely. In ACT V, Caliban comes to a conclusion that he must obey, since Prospero is more powerful. He becomes his own police force when he admits that he should be punished to death $(1993,5.1 .276)$, consequently he internalizes the social accepted standards, and reaches a "selffashioning" state, as Greenblatt devises the term (Renaissance Self-Fashioning 3).

Alonso and Sebastian, as the subversive characters, plot against the authority either in Milan or on the island: "My strong imagination sees a crown/ Dropping upon thy head" (1993, 2.1.208-209). Antonio is twice subversive, since he acts against the faculty of his panoptic self and he denies the existence of his conscience when Sebastian asks him if he has a conscience $(1993,2.1 .275)$. Scheming to kill the ruler of Milan, Antonio who needs help and support, goes through the process of containment. He tests Sebastian ideas, listens to him very carefully and ultimately manipulates his minds though justifying the claim for the throne: "Draw thy sword: one stroke/ Shall free thee from the tribute which thou payest;/ And I the king shall love thee" (1993, 2.1. 292-294).

The next subversive factor in the play reveals itself in the interactions among Caliban, Tricolu, and Stephano. Trincolu and Stephano manipulate Caliban through testing and they finally come to a conclusion that he is a feeble monster (1993, 2.2.145). As Caliban begins a negotiation and promises to serve his new master in order to get himself free from Prospero's service, Trincolu and Stephano listen to him carefully and record this “alien's voice," as Greenblatt mentions as part of the process of containment (2004, p.488). Stephano justifies his claim for the island by stating that "the king and all our company/else being drowned, we will inherit here" (1993, 2.2.174-175), consequently he reveals the potentials for subversion as well. Gradually Stephano builds up his own power state as he sets Caliban as his subject and warns Trincolu of any misconduct against Caliban.

Later Stephano threatens Trincolu of getting punished: "if you trouble him any more in's tale, by/ this hand, I will supplant some of your teeth" (1993, 3.2.49). Finally he promises his subject to destroy the other ruler (1993, 3.2.106107). However this subversion is partly contained by the help of Ariel as the police force: "I charm'd their ears/ That calf-like they my lowing follow'd through/ Tooth'd briers, sharp furzes, pricking goss and thorns,/ Which entered their 
frail shins: at last I left them/ I' the filthy-mantled pool beyond your cell” (1993, 4.1.178-182). This place that is devised behind Prospero's cell, is the reminiscent of a "Black Room" and a "Dutch Drowning Cell" which were used in the past for punishing the inmates, as Wilson remarks (2014, p.85). According to Foucault, a disciplinary system works best when the circumstances are set in a way that a "single gaze" incessantly monitors the inmate (1977, p.173). Later Prospero punished Caliban, Trincolu, and Stephano again by frightening them though magical shapes of dogs and hound so that they are rehabilitated and the subversive forces are contained.

According to Wilson, finally Prospero destroys his staff, since what matters is the life of the individuals and they should be beneficial for the society (2014, p.108). He remarks that Shakespeare's comedies are concerned with forgiveness, since power becomes stronger though rehabilitation and surveillance (2014, p.93). Based on this line of thought, Prospero pardons his enemies and he asserts that having mercy is more precious than revenge (1993, 5.1.27-28). Quite in the same manner, in the Epilogue, Prospero sets up a model of negotiation when he asks the spectators, who stand as the panoptic power, for mercy (Shakespeare, 1993, 19), and they are supposed to bestow amnesty to all the characters on the stage by applauding.

\section{Conclusion}

The major and minor panopticons presented in Shakespeare's The Tempest, have created a meta-panoptic structure in which there are negotiations between the subversive forces and the higher order. Subsequently the society of the play is disciplined via surveillance, punishment, and the ultimate containment of the disrupting vigor. Prospero as the ruler and the major panopticon, takes all the subjects under his unrelenting gaze and his police force rehabilitate the wrong doers. However since the perseveration of the self and individuals are of the prime importance during Renaissance, the play ends with Prospero's mercy upon his enemies. The minor panopticons in the play establish a police force for themselves and obtain a self-fashioning state. The process of testing, recording, and explaining is not thoroughly and pessimistically done though coercion, yet there are some opportunities for the lower orders to negotiate with the higher order. Ultimately it is revealed that containment is a negotiable personal, social, and cultural product.

\section{References}

Carey-Webb, A. (2014). Making Subject(s): Literature and the Emergence of National Identity. Routledge. Google book Search. Retrieved from https://books.google.com/books?id=15VIAwAAQBAJ\&pg

Chow, R. (2012). Entanglements, Or Transmedial Thinking about Capture. Duke UP.Google Book Search. Retrieved from https://books.google.com/books?id=KO3nIGdrx2oC\&pg

Campos, M. (2004). The Portrayal of Treason in The Tempest: The Fourfold Role of a Machiavellian Duke. Sederi, (14), pp.208-216.

Danaher, G. (2000). Understanding Foucault. Delhi: Motilal Banarsidass Publication.

Dollimore, J. (1994). Shakespeare, cultural materialism and the new historicism. In J. Dollimore \& A. Sinfield (Eds.), Political Shakespeare: Essays in Cultural Materialism (Illustrated, reprint, revised ed.). Manchester: Manchester University Press. Google Book Search. Retrieved from https://books.google.com/books?id=BctZMVhGkHEC\&pg

Dreyfus, H., \& Rabinow, P.(1983). Michel Foucault, beyond structuralism and hermeneutics (2nd ed.). Chicago: University of Chicago Press.

Foucault, M. (1977). Discipline and Punish: The Birth of the Prison. New York: Pantheon.

-----. (2004) “Discipline and Punish.” Literary Theory, an Anthology. Ed. Julie Rivkin and Michael Ryan. 2 nd ed. Malden, MA: Blackwell.

Fumerton, P,\& Simon H. (Eds.). (1999). Renaissance Culture and the Everyday. U of Pennsylvania. Google Book Search. Retrieved from https://books.google.com/books?id=4TSde5LI40EC\&pg

Grady, H. Containment Subversion -and Postmodernism. (1993). Textual Practice. Ed. Terence Hawkes. Vol. 1. Psychology. Google Book Search. Retrieved from https://books.google.com/books?id=jq331W-M9ZYC\&pg

Greenblatt, S. (2004). Invisible Bullets: Renaissance Authority and Its Subversion, Henry IV and Henry V. Shakespeare: An Anthology of Criticism and Theory, 1945-2000. Ed. Russ McDonald. Malden, MA: Blackwell Pub.

-----.(2012). Renaissance Self-Fashioning: From More to Shakespeare. U of Chicago. Google Book Search. Retrieved from https://books.google.com/books?id=XHxWpdvvUs0C\&printsec

-----. (1988). Shakespearean Negotiations: The Circulation of Social Energy in Renaissance England. U of California. Google Book Search. Retrieved from https://books.google.com/books?id=866eoQY-tXIC\&printsec

Hawkes, T. (2005). Textual Practice: Volume 7, Issue 2. Routledge. Google Books Search. Retrieved from https://books.google.com/books?id=Fo2JAgAAQBAJ\&dq

Lim, W. (1998). The arts of empire: The poetics of colonialism from Ralegh to Milton (Illustrated ed.). Newark: University of Delaware Press. Google Book Search. Retrieved from

https://books.google.com/books?id=4OVranlVxhcC\&pg 
Merkel, M. (2013, October 25) Sources and Design of Shakespeare's Tempest. Edward Oxford Review. Retrieved from Http://www.edwardoxenford.org/tag/sources-and-design-of-shakespeares-tempest

McDonald, R. (Ed.). (2004). Shakespeare: An anthology of criticism and theory, 1945-2000. Malden, Mass.: Blackwell Pub.

Montrose, L.A. (1996). The Purpose of Playing: Shakespeare and the Cultural Politics of the Elizabethan Theatre. U of Chicago. Google Book Search. Retrieved from https://books.google.com/books?id=SVTsYd9C274C\&dq

-----. (2004). Shaping Fantasies: Figurations of Gender and Power in Elizabethan Culture. Shakespeare: An Anthology of Criticism and Theory, 1945-2000. Ed. Russ McDonald. Malden, MA: Blackwell Pub.

Pieters, J. (2001). The Tempest and Its Histories. In Moments of Negotiation: The New Historicism of Stephen Greenblatt . Amsterdam: Amsterdam University Press. Google Book Search. Retrieved from https://books.google.com/books?id=a0Uf3ocKl_QC\&pg

Prusko, R. (2013) ‘A Bootless Inquisition'? Reconsidering Miranda. The Tempest Seminar. 2013. Shakespeare Association of America. Retrieved from http://www.shakespeareassociation.org/wpcontent/uploads/2014/08/2013-Abstract-50.pdf

Rivkin, J., \& Ryan, M. (Eds.). (2004). Literary theory, an anthology (2nd ed.). Malden, Mass.: Blackwell. Shakespeare, W. (1993). The Tempest: Entire Play. Retrieved from http://shakespeare.mit.edu/tempest/full.html Shaughnessy, R. (2013). The Routledge Guide to William Shakespeare. Routledge. Google Book Search. Retrieved from https://books.google.com/books?id=yJN4yAsNSYEC\&pg>.

Schneider, Jr., B. (1995). “Are We Being Historical Yet?” Colonialist Interpretations of Shakespeare's Tempest. In J. Barroll (Ed.), Shakespeare studies (Illustrated ed., Vol. 23, pp.120-142). Madison, N.J.: Fairleigh Dickinson Univ Press.

Wilson, R. (2014). Shakespeare in French Theory: King of Shadows. London: Routledge.

Officer Ranks in the Royal Navy. (2000). Retrieved from $\mathrm{http} / / /$ www.royalnavalmuseum.org/info_sheets_nav_rankings.htm\#Flag

Parts of Boats and Ships. (n.d.). Retrieved from http\%3A\%2F\%2Fwww.macmillandictionary.com\%2Fthesauruscategory $\% 2$ Fbritish $\% 2$ Fparts-of-boats-and-ships

What are Fractals? (2013). Retrieved from http://fractalfoundation.org/resources/what-are-fractals/

Notes

'According to Dollimore "Cultural Materialism," which is first used by Raymond Williams, is concerned with the exploration of the culture during the post-war era in England. Recently the critics have associated cultural material with the literature, thoughts, and ideology of Renaissance period (1994, pp.2-3).

ii "A fractal is a never-ending pattern. Fractals are infinitely complex patterns that are self-similar across different scales" $(2013$, p.1) 